УДК 581.1

DOI 10.30679/2219-5335-2021-6-72-160-175

ОПРЕДЕЛЕНИЕ

В ЛИСТЬЯХ РАСТЕНИЙ

СОДЕРЖАНИЯ

ЖАСМОНОВОЙ КИСЛОТЫ

И МЕТИЛЖАСМОНАТА

Лепешкина Светлана Васильевна

научный работник библиотеки

Федеральное государственное

бюджетное научное учреждение

«Северо-Кавказский федеральный

научный центр садоводства,

виноградарства, виноделия»,

Краснодар, Россия

Жасмоновая кислота и ее метиловый эфир проявляют различные физиологические и биохимические эффекты в широком спектре клеточных процессов растений. Однако достоверной доступной методики определения их массовой концентрации в сложных биологических объектах не существует. В качестве объектов исследования были свежие листья Hibiscus rosa-chinensis, Sansevieria, Juglans regia L., Morus, Vítis. Цель исследований заключалась в совершенствовании аналитической методики количественного определения массовой концентрации жасмоновой кислоты и метилжасмоната, разработке условий подготовки проб для анализа. Для выполнения работы использованы анализатор капиллярный ионный электрофоретический «Капель 104Т», хроматограф газовый «Кристалл 2000М», газовый хроматомасс-спектрометр GC-MS Perkin Elmer Clarus 600T. Проведено апробирование методики капиллярного электрофореза и капиллярной газовой хроматографии для количественного определения метилжасмоната. Установлена непригодность метода капиллярного электрофореза для прямого определения метилжасмонта и показана возможность определения
UDC 581.1

DOI 10.30679/2219-5335-2021-6-72-160-175

\section{DETERMINATION \\ OF THE CONTENT \\ OF JASMONIC ACID \\ AND METHYL JASMONATE \\ IN PLANT LEAVES}

\section{Lepeshkina Svetlana Vasilievna}

Library Scientist

\section{Federal State Budget \\ Scientific Institution \\ «North Caucasian Federal \\ Scientific Center of Horticulture, \\ Viticulture, Wine-making», \\ Krasnodar, Russia}

Jasmonic acid and its methyl ester exhibit various physiological and biochemical effects in a wide range of plant cellular processes. However, there is no reliable available method for determining their mass concentration in complex biological objects.

The objects of research were fresh leaves of Hibiscus rosa-chinensis, Sansevieria, Juglans regia L., Morus, Vítis.

The aim of the research was to improve the analytical method for the quantitative determination of the mass concentration of jasmonic acid and methyl jasmonate, to develop the conditions for preparing samples for analysis. To carry out the work, a capillary ion electrophoretic analyzer "Kapel 104T", a gas chromatograph "Kristall 2000M", a gas chromatography-mass spectrometer GC-MS Perkin Elmer Clarus 600T were used. The approbation of the method of capillary electrophoresis and capillary gas chromatography for the quantitative determination of methyl jasmonate was carried out. The unsuitability of the method of capillary electrophoresis for the direct determination of methyl jasmont was established, and the possibility of determining methyl jasmonate 
метилжасмоната после экстракции гексаном методом капиллярной газовой хроматографии. Применено повышенное дозирование пробы гексанового экстракта в хроматограф, позволившее достичь необходимого уровня чувствительности анализа. Показано применение метода ГХ-МС для идентификации метилжасмоната в гексановом экстракте листьев с порогом

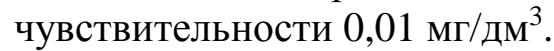
Экспериментально найдены условия гидролиза растительных образцов - время экспозиции и концентрация калийной щелочи. Для последующего количественного определения жасмоновой кислоты использован метод капиллярного электрофореза, применен электролит на основе борной кислоты. Полнота гидролиза эфиров жасмоновой кислоты проверена на растворах метилжасмоната. Получены данные по содержанию метилжасмоната и жасмоновой кислоты в биологических объектах.

Ключевые слова: ЖАСМОНОВАЯ КИСЛОТА, РАСТИТЕЛЬНЫЙ МАТЕРИАЛ, ЭКСТРАКТ, ГИДРОЛИЗ, АНАЛИЗ, ХРОМАТОГРАФИЯ after extraction with hexane by capillary gas chromatography was shown.

An increased dosage of the hexane extract sample into the chromatograph was applied, which made it possible to achieve the required level of analysis sensitivity. Application of GC-MS method for identification of methyl jasmonate in hexane extract of leaves with a sensitivity threshold of $0.01 \mathrm{mg} / \mathrm{dm}^{3}$ is shown. The conditions of hydrolysis of plant samples - exposure time and concentration of potassium alkali - were found experimentally. For the subsequent quantitative determination of jasmonic acid, the method of capillary electrophoresis was used; an electrolyte based on boric acid was used. The completeness of hydrolysis of jasmonic acid esters was tested on solutions of methyl jasmonate. Data on the content of methyl jasmonate and jasmonic acid in biological objects were obtained.

Key words: JASMONIC ACID, PLANT MATERIAL, EXTRACT, HYDROLYSIS, ANALYSIS, CHROMATOGRAPHY

Введение. Проведение листовой диагностики путем определения подвижных форм щелочных и щелочноземельных металлов, микроэлементов, органических и некоторых фенольных кислот, фитогормонов представляет собой оперативный метод контроля физиологического состояния плодовых культур и винограда, а также может служить критерием иммунной устойчивости сорта. Диагностика позволяет следить за степенью развития и активацией физиологических процессов.

В последние десятилетия фитофизиологами активно изучаются функции оксилипинов - биологически активных молекул, образующихся в ходе окисления полиненасыщенных жирных кислот. Интерес, проявляемый ныне к окислительному метаболизму жирных кислот в растениях, в значительной степени связан с успехами в исследовании простагландинов, 
лейкотриенов, липоксинов, тромбоксанов и других оксигенированных $\mathrm{C}_{20}$-полиеновых жирных кислот, получивших групповое название «эйкозаноиды». Сигнально-регуляторные функции этих соединений в животных клетках изучены весьма подробно. Для растений более характерными оказались ненасыщенные жирные кислоты октадеканоидного ряда. К настоящему времени в целом выяснен каскад реакций превращения $\mathrm{C}_{18}$-жирных кислот, в результате которых образуется широкий спектр различных оксигенированных продуктов. Среди них такие известные физиологически активные соединения, как жасмоновая кислота и ее производные. У растений жасмонаты рассматриваются как структурные и, в некоторых случаях, функциональные аналоги простагландинов животных. Жасмонатный сигналинг относительно подробно изучен на примере двудольных - арабидопсиса (Arabidopsis thaliana), томатов (Solanum lycopersicum), табака (Nicotiana tabacum) и в меньшей степени некоторых однодольных - ячменя (Hordeum vulgare) и риса (Oryza sativa).

К числу физиологических процессов, зависимых от жасмонатов, относятся созревание семян, образование жизнеспособной пыльцы, рост корней, запуск программы старения, защитные ответы на действие биотических и абиотических стрессоров.

Многие авторы рассматривают жасмонаты как класс фитогормонов, хотя существует точка зрения, что их нельзя считать фитогормонами, поскольку их физиологические концентрации значительно выше, чем у классических растительных гормонов. При этом, однако, широкий спектр сигнально-регуляторных функций жасмоновой кислоты и ее производных дает основание считать эти соединения новыми естественными регуляторами роста и развития растений. Жасмоновая кислота и ее производные, вместе именуемые жасмонатами, являются оксилипидными растительными гормонами стресса, которые присутствуют во всем растительном мире. Они вырабатываются у мхов, грибов, голосеменных и покрытосеменных расте- 
ний. Жасмоновая кислота образуется в листьях и некоторые этапы биосинтеза могут протекать в корнях [1-6].

Жасмоновая кислота может образовываться при деградации мембранных липидов разными путями. Один из наиболее изученных каскадов, приводящих к образованию жасмоновой кислоты, начинается с окисления липоксигеназой $\alpha$-линоленовой кислоты, которая высвобождается из галоктолипидов мембран хлоропластов при участии фосфолипазы 1 [3], до 13-гидропероксилиноленовой (13-гидроперокси-октадекатриеновой) под действием 13-липоксигеназы (13(S)-LOX) [2]. Эта кислота является субстратом для синтеза и дегидрируется алленоксидсинтазой, образуя нестабильную 12,13-эпоксиоктадекатриеновую кислоту, которая циклизируется алленоксидциклазой, при участии не менее 5 ферментов (липаза, липоксигеназа, синтаза и циклаза оксида аллена и редуктаза OPDA) [7], приводящей к образованию 12-оксо-фитодиеновой кислоты (12-оксо-ФДК) - первому пентациклическому производному этого пути. Затем это соединение с помощью 12-оксо-ФДК-редуктазы превращается в 12-оксофитоеновую ((3-оксо-2-(2Z)-пентенил)-циклопентан октановую) кислоту. После этого происходит укорачивание боковой цепи за счет трех последовательных реакций $\beta$-окисления с образованием жасмоновой кислоты $[8,9]$.

В 1984 году было дано одно из первых представлений синтеза жасмоната, сигнальной молекулы оксилипина в растениях [11]. Жасмоновую кислоту, синтезированную ферментативно по пути оксилипина, рассматривают как структурные и функциональные аналоги простагландинов у животных. Жасмоновая кислота регулирует многие гены растений, участвующие в ответе на изменения условий окружающей среды, поэтому жасмонаты являются необходимыми гормонами для выживания и развития растений $[2,3,12]$. Растения реагируют на различные стрессы окружающей среды, такие как высокие и низкие температуры, соленость, засуха, УФ излучения, недостатке воды, влияния патогенных микроорганизмов 
$[2,10,13,14,15]$. Метилжасмонат - это соединение природного происхождения, которое было обнаружено в растениях девяти семейств и использовалось как ароматизатор духов (запах жасмина) долгие десятилетия. Содержание жасмонатов в тканях растений отличается на разных этапах развития и являются ответом на воздействия внешней среды. Высокие уровни жасмонатов обнаружены в цветках и тканях перикарпа, а также в хлоропластах на свету. Уровни жасмонатов быстро возрастают в ответ на механические помехи, например, при закручивании усиков и при возникновении повреждения, при изменении тургорного давления в ходе недостатка воды, при взаимодействии корневых волосков с частицами почвы [15-18].

Известно, что это вещество проявляет различные физиологические и биохимические эффекты в широком спектре клеточных процессов растений, включая дыхание, ингибирование роста стеблей и корней, усиленное свертывание, клубневание, старение листьев, плодородие, созревание фруктов, ингибирование образования хлорофилла и синтеза каротиноидов, снижение фотосинтеза и дыхательной активности. Например, JA, находящаяся в вегетативных клетках, регулирует рост круток, а ЈА, производимая в цветах, регулирует созревание пыльцы $[5,8,11]$. Большое количество жасмоновой кислоты накапливается в цветках и плодах, вероятно, это связано с созреванием плодов и накоплением каротиноидов в растениях. Однако, инициирование и запуск биосинтеза жасмоновой кислоты - это давний и открытый вопрос $[2,7]$.

Высокие уровни жасмоновой кислоты стимулируют накопление запасных белков и тем самым оказывают влияние на формирование клубней $[7,20]$. МеЈ учувствует не только в ответных реакциях на развитие растения, но и индуцируется при атаке микроорганизмов [13]. Известны различные аналитические методы определения жасмонатов, в том числе радиоиммунный анализ, фермент-связанный иммунносорбентный анализ, ГХ$\mathrm{MC}$, высокоэффективная жидкостная хроматография. В основном они тре- 
буют наличия сложной аналитической аппаратуры и особых условий подготовки проб: методика ВЭЖХ требует применения водноацетонитрильной среды [21,22].

Цель исследований заключалась в совершенствовании аналитической методики количественного определения массовой концентрации жасмоновой кислоты (JA) и метилжасмоната (MeJ), в оценке условий подготовки проб для анализа.

Объекты и методы исследований. В качестве объектов исследований были свежие листья цветочных культур - Hibiscus rosa-chinensis, Sansevieria, Juglans regia L., Morus, Vítis различной степени зрелости. Для выполнения работы использованы следующие приборы центра коллективного пользования «Приборно-аналитический»:

- анализатор капиллярный ионный электрофоретический «Капель 104T»;

- хроматограф газовый “Кристалл 2000М”, снабженный пламенноионизационным детектором и кварцевой капиллярной колонкой;

- газовый хроматомасс-спектрометр GC-MS Perkin Elmer Clarus 600T (USA), оборудованный автодозатором и капиллярной колонкой Elite-Wax ETR.

Обсуждение результатов. Учитывая тот факт, что молекула метилжасмонат содержит непредельную связь и должна обладать поглощением УФ-излучения, для возможного определения этого вещества был использован метод капиллярного электрофореза, который обладает высокой чувствительностью и сепарационной способностью для подобного класса веществ. Использована система капиллярного электрофореза «Капель 104Т», оснащенная ультрафиолетовым фотометрическим детектором, работающим на длине волны 254 нм, кварцевым капилляром, длиной не менее 0,5 м до детектора, внутренним диаметром от 75 мкм, источником высоко- 
го напряжения положительной полярности с регулируемым напряжением от 1 до 25кВ и персональным компьютером с соответствующим программным обеспечением для сбора и обработки информации. Вместо уверенного сигнала получены хаотичные шумы, которые нельзя считать пиком аналита, поэтому дальнейшие эксперименты по возможному применению капиллярного электрофореза были признаны несостоятельными и исследования прекращены.

Учитывая определенную летучесть метилжасмоната в следующем исследовании для создания методики выполнения измерений использован метод капиллярной газовой хроматографии. Для исследования применен хроматограф газовый «Кристалл 2000М», снабженный пламенноионизационным детектором и кварцевой капиллярной колонкой.

Для проведения анализа выбран режим с программированием температуры:

- капиллярная кварцевая колонка, внутренним диаметром 0,32 мм, длина 50 м;

- нанесенная фаза - ФФАП (FFAP);

- температура дозатора - $150{ }^{\circ} \mathrm{C}$;

- подогрев детектора ПИД - $180{ }^{\circ} \mathrm{C}$;

- давление входное на колонке 54,1 кПа;

- температурный режим колонки $90{ }^{\circ} \mathrm{C}$, изотермическая выдержка 2 мин, далее старт программирования температуры со скоростью $10^{\circ} \mathrm{C} /$ мин до конечной температуры $170{ }^{\circ} \mathrm{C}$, далее выдержка 40 мин при $170{ }^{\circ} \mathrm{C}$ и нагрев со скоростью $10^{\circ} \mathrm{C} /$ мин до конечной температуры $190{ }^{\circ} \mathrm{C}$; дозатор с делителем потока газа-носителя - с установленным коэффициентом деления потока - 1:31; расход газа-носителя через колонку 0,95 см³ / мин; объем дозируемой пробы аналита - 1,5 мм³; газ-носитель, используемый в анализе, - особо чистый азот; объемная скорость водорода $20 \mathrm{~cm}^{3} /$ мин; воздуха - $200 \mathrm{~cm}^{3} /$ мин; усредненное время анализа - 70 мин. 
Для расчетов количественного содержания веществ в пробе был использован метод абсолютной градуировки, обеспечивающий качественные результаты. На рисунке 1 показана хроматограмма градуировочного раствора метилжасмоната в 50 \% этаноле, массовая концентрация 25 мг/дм³.

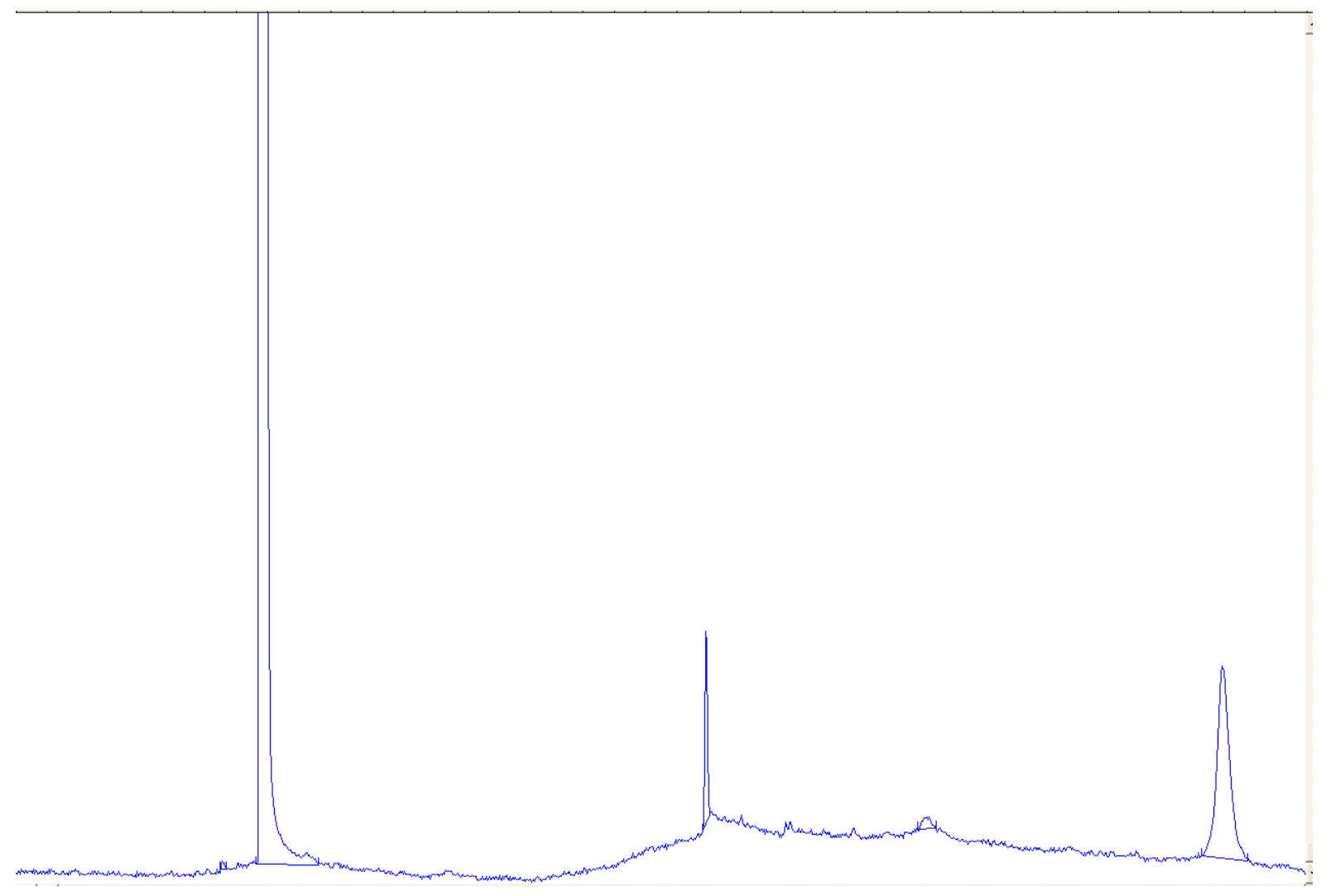

Рис. 1. Хроматограмма градуировочного раствора метилжасмоната, спирт этиловый 50\%, концентрация аналита 25 мг/дм ${ }^{3}$

Учитывая физико-химические свойства метилжасмоната и в первую очередь его растворимость, было решено для экстракции из растительных объектов использовать гексан. Гексан - неполярный растворитель и должен обеспечить минимум веществ в экстракте, за исключением интересующего аналита. Первоначально для корректировки методики были выбраны листья комнатных растений - Hibiscus rosa-chinensis, Sansevieria. Была проверена возможность повышения чувствительности анализа реальной про-

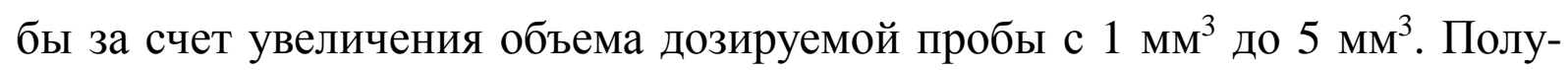


ченный результат свидетельствовал о недостаточной чувствительности данного приема, полезный сигнал практически невозможно было выделить из базовой линии хроматограммы. Полученные данные позволили прийти к выводу, что для гексанового экстракта следует использовать дозировки не менее 5 мм³ $^{3}$ Следующим объектом анализа были свежие листья винограда гибридного сорта. Для количественного определения метилжасмоната листья винограда были взвешены на технических весах. Далее листья растирали в ступке до кашеобразного состояния и переносили в пробирки из полимерного материала объемом $15 \mathrm{~cm}^{3}$ с завинчивающейся крышкой. Далее к объектам было добавлено 5 cм$^{3}$ гексана для получения экстракта. Настаивание сырья с растворителем проводили от 25 до 45 мин. Верхний прозрачный слой отбирали микрошприцом и дозировали в хроматограф. Найденная концентрация метилжасмоната составила 0,12 мг/кг для листьев винограда, 0,55 мг/кг для Hibiscus rosa-chinensis, и 0,78 мг/кг для Sansevieria.

В связи с тем, что при анализе растительных образцов возможно появление пиков других веществ, кроме метилжасмоната, была оценена возможность использования метода ГХ-МС для идентификации метилжасмоната в сложных пробах и при получении спорных результатов.

Для проведения идентификации метилжасмоната использован газовый хроматомасс-спектрометр GC-MS Perkin Elmer Clarus 600T (USA), оборудованный автодозатором и капиллярной колонкой Elite-Wax ETR длиной 50 м, внутренний диаметр 0,32 мм. Анализ продолжительностью 45 мин проводили в следующих условиях:

- температура дозатора - $215^{\circ} \mathrm{C}$;

- подогрев детектора - $180^{\circ} \mathrm{C}$;

- давление входное на колонке 61,5 кПа;

- температурный режим колонки $70{ }^{\circ} \mathrm{C}$, далее старт программирования температуры со скоростью $5^{\circ} \mathrm{C} /$ мин до конечной температуры $220^{\circ} \mathrm{C}$ и изотерма 20 мин, до окончания анализа; 
Плодоводство и виноградарство Юга России № 72(6), 2021 г.

- дозатор с делителем потока газа-носителя - 1:20;

- расход газа-носителя через колонку $1,50 \mathrm{~cm}^{3} /$ мин;

- объем дозируемой пробы аналита - 1 мм³ $^{3}$;

- газ-носитель, используемый в анализе - особо чистый гелий;

Детектирование осуществляли по выбранным характеристическим ионам с m/z 83 (целевой) и $\mathrm{m} / \mathrm{z} 141$, электронная ионизация в режиме c включением детектора через 7 мин после дозирования пробы в инжектор (для исключения влияния большой концентрации растворителя на итоговый результат анализа). Количественное определение метилжасмоната проводили по площади иона с m/z 83; 141. Результаты идентификации чистого вещества показаны на рис. 2-4.

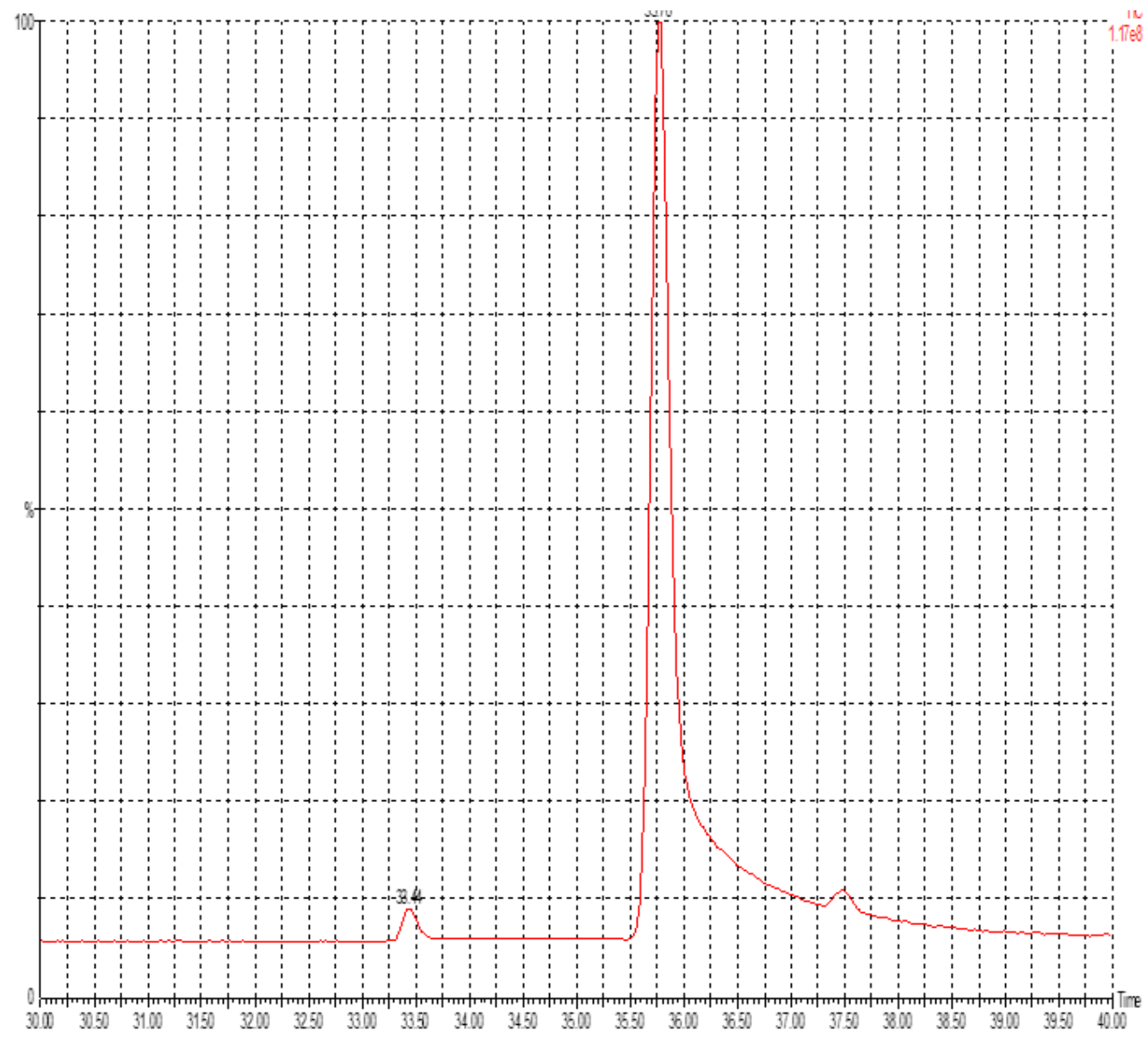

Рис. 2. Хроматомасс-спектрограмма метилжасмоната, спиртовый раствор 


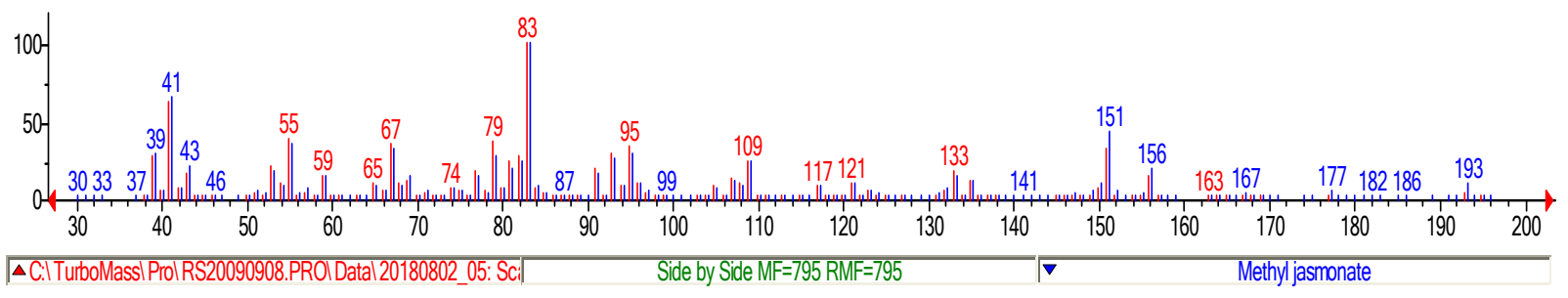

Рис. 3. Библиотечный спектр метилжасмоната

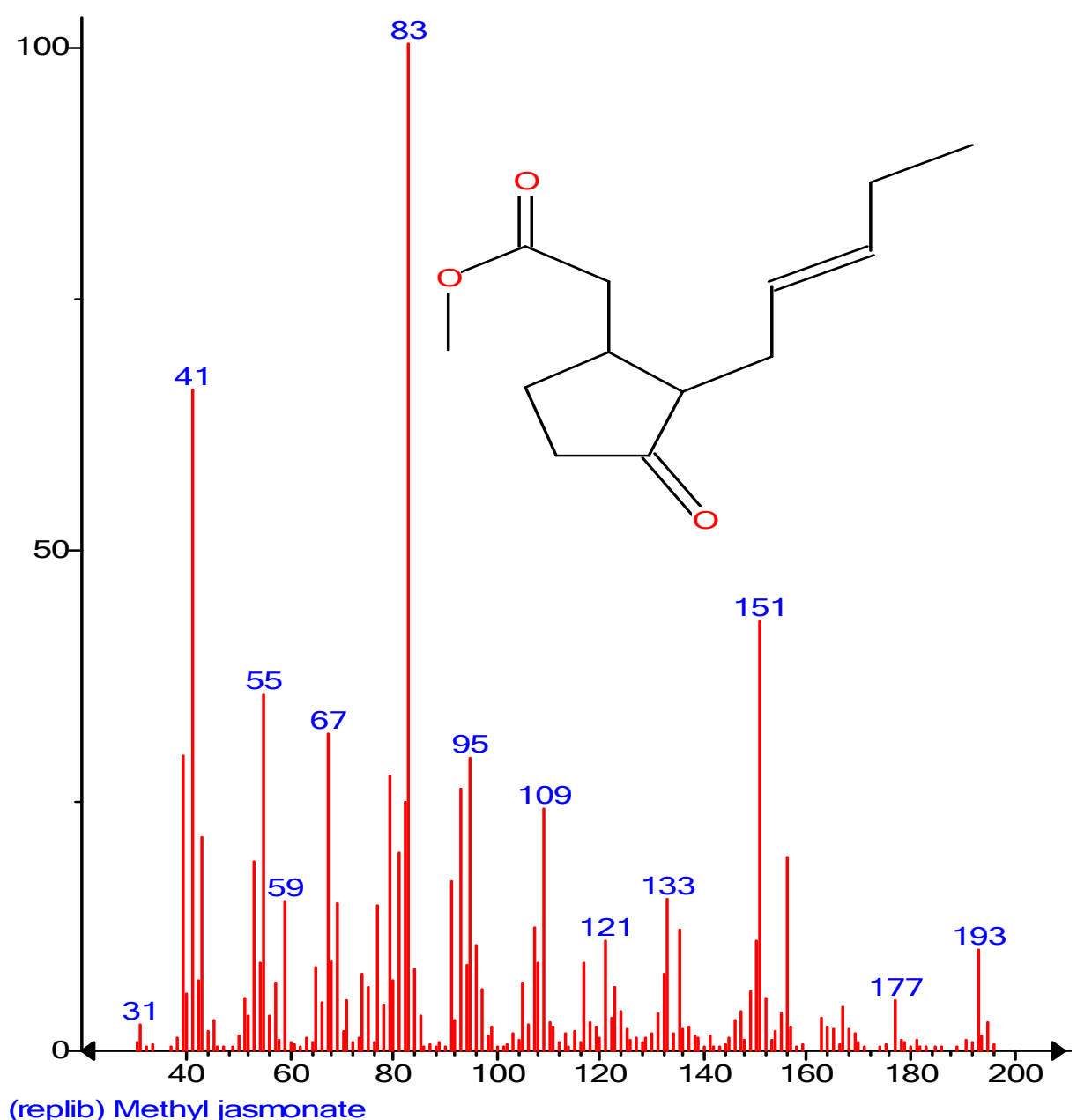

Рис. 4. Характеристический масс-спектр метилжасмоната

Name: Methyl jasmonate

Formula: $\mathrm{C}_{13} \mathrm{H}_{20} \mathrm{O}_{3}$

MW: 224 CAS\#: 1211-29-6 NIST\#: 211137 ID\#: 10248 DB: replib

Полученные данные (рис. 2 и библиотечный спектр метилжасмоната) свидетельствуют о том, что метод ГХ-МС может быть применен для решения спорных вопросов при определении метилжасмоната в 
Плодоводство и виноградарство Юга России № 72(6), 2021 г.

растительных объектах. Были сделаны отборы проб растительного сырья (листья): грецкий орех, виноград, шелковица и был организован эксперимент по возможности установления общего содержания жасмоновой кислоты (JA) после гидролиза в водном растворе калийной щелочи.

Использован водный электролит для прямого определения компонента, учитывая, что жасмоновая кислота обладает существенным поглощением УФ-излучения. Один из таких наиболее универсальных электролитов: борная кислота $(0,3 \%)$, тетраборат натрия 12-ти водный $(0,08 \%)$.

Приготовление раствора борной кислоты массовой концентрацией 0,3\% и 0,08 \% тетрабората натрия 12-ти водного:

В мерную колбу вместимостью 100 см$^{3}$ вносят 50-60 см³ дистиллированной воды, добавляют $(0,300 \pm 0,002)$ г борной кислоты и $(0,08 \pm 0,001)$ г тетрабората натрия 12-ти водного, перемешивают до полного растворения. Затем доводят до метки дистиллированной водой и перемешивают. Срок хранения этого раствора при комнатной температуре - не более 1 мес.

Выполнение анализа.

Положительное напряжение на капилляре устанавливают равным 23 кВ. Длина волны детектирования 254 нм. Дозирование пробы пневматическое - 30 мБар, в течение 5 сек. Результаты анализа растворов гидролизатов на предмет содержания жасмоновой кислоты показаны в таблице.

Разная степень гидролиза производных жасмоновой кислоты в листьях растений, по-видимому, объясняется стабильностью веществ, в которых она присутствует в данном растении и связана с биологией вида. Это прослеживается на примере 10 \% щелочи: степень гидролиза для шелковицы достаточно велика, но совершенно низкая для винограда и грецкого ореха. Не исключено, что это связано с биологией вида: грецкий орех и виноград более теплолюбивые культуры и менее приспособлены к быстрой адапта- 
Плодоводство и виноградарство Юга России № 72(6), 2021 г.

ции - жасмонаты находятся в более устойчивых формах соединений, менее подвержены гидролизу.

Таблица - Результаты анализа гидролизатов листьев, мг/кг, Р=0,95

\begin{tabular}{|c|c|c|c|}
\hline Наименование образца & $\begin{array}{c}\text { Грецкий } \\
\text { орех }\end{array}$ & $\begin{array}{c}\text { Виноград сорта } \\
\text { Изабелла }\end{array}$ & Шелковица \\
\hline 1 сутки, $10 \%$ щелочь & 1,2 & 0 & 32,6 \\
\hline 1 сутки, 25\% щелочь & 26,2 & 29,5 & 43,2 \\
\hline 1 сутки, 30\% щелочь & 24,5 & 4,2 & 37,1 \\
\hline 1 сутки, 40\% щелочь & 12,4 & 3,0 & 30,2 \\
\hline 1 сутки, 50\% щелочь & 18,4 & 0 & 14,6 \\
\hline 3 сутки, $10 \%$ щелочь & 1,8 & 2,4 & 3,7 \\
\hline 3 сутки, 25\% щелочь & 13,2 & 14,8 & 13,9 \\
\hline 3 сутки, 30\% щелочь & 12,4 & 16,3 & 0 \\
\hline 3 сутки, 40\% щелочь & 10,4 & 0 & 0 \\
\hline 3 сутки, 50\% щелочь & 0 & 0 & 2,2 \\
\hline 6 сутки, $10 \%$ щелочь & 5,7 & 4,3 & 4,7 \\
\hline 6 сутки, 25\% щелочь & 7,8 & 5,9 & 0 \\
\hline 6 сутки, 30\% щелочь & 0 & 0 & 0 \\
\hline 6 сутки, 40\% щелочь & 0 & 0 & 0 \\
\hline 6 сутки, 50\% щелочь & 0 & & 0 \\
\hline
\end{tabular}

Оптимальной для изучаемых видов растительного сырья оказалась концентрация калийной щелочи $25 \%$. Существенное влияние на процесс оказывала длительность экспозиции: гидролиз в течение 3-х суток приводил к потерям аниона жасмоновой кислоты, она не обнаруживалась при концентрации щелочи 40 \% и более. Анион жасмоновой кислоты практически не обнаруживался при экспозиции 6 суток. 
Плодоводство и виноградарство Юга России № 72(6), 2021 г.

Заключение. Проведено тестирование методики капиллярного электрофореза и капиллярной газовой хроматографии для определения метилжасмоната. Установлена непригодность метода капиллярного электрофореза для определения метилжасмонта. Показана возможность определения метилжасмоната методом капиллярной газовой хроматографии и выполнена идентификация метилжасмоната методом ГХ-МС с порогом чувствительности 0,01 мг/дм³ . Разработаны и обоснованы условия гидролиза растительного сырья калийной щелочью ( $25 \%$-ной) и количественного определения жасмоновой кислоты методом капиллярного электрофореза. Полнота гидролиза проверена на растворах метилжасмоната. Получены данные по содержанию метилжасмоната - 0,12-0,78 мг/кг и общей жасмоновой кислоты 26,2-43,2 мг/кг биологического объекта.

\section{Литература}

1. Balbi, V. Jasmonate signalling network in Arabidopsis thaliana: crucial regulatory nodes and new physiological scenarios / V. Balbi, A. Devoto // New Phytol. - 2008 - V. 177 - P. 301-318.

2. Chini, A. The JAZ family of repressors is the missing link in jasmonate signaling / A. Chini, S. Fonseca, G. Fernandez // Nature. - 2007 - V. 448 - P. 666-671.

3. Вильданова М.С. Реакция культивируемых нормальных и опухолевых клеток кожи человека на действие растительных гормонов : автореф. дис. ... канд . биол. наук : 03.03.04 / Вильданова Мария Сергеевна. М., 2016. 19 с.

4. Hyun, Y. Cooperation and functional diversification of two closely related galactolipase genes for jasmonate biosynthesis / Y. Hyun [et all] // Dev. Cell. - 2008 - V. 14 - P. 183-192.

5. Hyun, Y. Generating and maintaining jasmonic acid in Arabidopsis / Y. Hyun, I. Lee // Plant Signal. Behav. - 2008 -V. 3 - P. 798-800.

6. Keramat, B. Effects of methyl jasmonate in regulating cadmium induced oxidative stress in soybean plant (Glycine max L.) / B. Keramat, K.M. Kalantari, M.J. Arvin // Afr. J. Microbiol. Res. - 2009 - V. 3, № 5 - P.240-244.

7. Agrawal, G.K. Rice octadecanoid pathway / G.K. Agrawal [et al.] // Biochem. and Biophys. Res.Commun. - 2004. - V. 317, № 1. - P. 1-15.

8. Creelman, R. Biosynthesis and action of jasmonates in plants. / R. Creelman, J.E.Mullet // Annu. ReV. Plant Physiol. Plant Mol. Biol. - 1997. - V. 48. - P. 355-381.

9. Колупаев Ю.Е., Карпец Ю.В. Жасмоновая кислота у растений: синтез, сигналинг и физиологические эффекты при стрессах // Вестник Харьковского национального аграрного университета серия биология. 2010. Вып. 1 (19). С. 21-23.

10. Liechti, R. The jasmonate pathway. / R. Liechti, E.E. Farmer // Science. - 2002. V. 296. - P.1649-1650.

11. Kazan, K. Jasmonate signaling: toward an integrated view / K. Kazan, J.M. Manners // Plant Physiol. - 2008. - V. 146. - P. 1459-1468. 
12. Anderson, J.M. Jasmonic acid-dependent increases in the level of specific polypeptides in soybean suspension culture seedlings / Journal of Plant Growth Regulation. 2005. - V. 7. - P. $203-211$.

13. Ali, B.M. Methyl jasmonate and salicylic acid elicitation induces ginsenosides accumulation, enzymatic and nonenzymatic antioxidant in suspension culture Panax ginseng roots in bioreactors / B.M. Ali [et all] // Plant Cell Rep. - 2006. - V. 25, № 6. - P. 613-620.

14. Gao, X.P. Jasmonic acid is involved in the water-stress-induced betaine accumulation in pear leaves / X.P. Gao [et al.] // Plant Cell Environ. - 2004. - V. 27, №4. P. 497-507.

15. Hristova, V.A. Possible role of methyl jasmonate in protection to paraquat-induced oxidative stress in barley plants / V.A. Hristova, L.P. Popova // Докл. Бълг. АН. - 2002. V. 55, № 8. - P. 99-104.

16. Farmer, E.E. Interplant communication: airborne methyl jasmonate induces synthesis of proteinase inhibitors in plant leaves. / E.E. Farmer, C.A. Ryan // Proc. Natl. Acad. Sci. U.S.A. - 1990. - V. 87. - P. 7713-7716.

17. https://studopedia.su/10_142881_lektsiya----sinteticheskie-regulyatori-rosta-irazvitiya-rasteniy.html

18. Gaspar, Th. Changing concepts in plant hormone action / Th. Gaspar [et al.] // In Vitro Cell Dev. Biol. Plant. - 2003. - V. 39, № 2. - P. 85-106.

19. Anderson, J.M. Jasmonic acid-dependent increase in vegetative storage protein in soybean tissue culture / J. Plant Growth Regul. - 1991- V. 10. - P. 5-10.

20. Neurasthenia, A. Inhibitory effects of methyl jasmonate on seed germination in maize (Zea Mays): effect on $\alpha$-amylase activity and ethylene production / A. Neurasthenia [et all] // Gen. Appl. Plant Physiology. - 2007. - V.33, (1-2). - P.13-23.

21.YaQian, L. Electrochemical behavior and the determination of methyl jasmonate / L. YaQian, W. Fang, C. Zilin // Chinese Science Bulletin. - 2010. - V. 55, (21). P. 2225-2230

22. Simultaneous determination of salicylic acid, jasmonic acid, methyl salicylate, and methyl jasmonate from ulmus pumila leaves by GC-MS / Zhi-hong Huang [et al.] // International Journal of Analytical Chemistry.- 2015.- Article ID 210503

\section{References}

1. Balbi, V. Jasmonate signalling network in Arabidopsis thaliana: crucial regulatory nodes and new physiological scenarios / V. Balbi, A. Devoto // New Phytol. - 2008 - V. 177 - P. 301-318.

2. Chini, A. The JAZ family of repressors is the missing link in jasmonate signaling / A. Chini, S. Fonseca, G. Fernandez // Nature. - 2007 - V. 448 - P. 666-671.

3. Vil'danova M.S. Reakciya kul'tiviruemyh normal'nyh i opuholevyh kletok kozhi cheloveka na dejstvie rastitel'nyh gormonov : avtoref. dis. ... kand . biol. nauk : 03.03.04 / Vil'danova Mariya Sergeevna. M., 2016. 19 s.

4. Hyun, Y. Cooperation and functional diversification of two closely related galactolipase genes for jasmonate biosynthesis / Y. Hyun [et all] // Dev. Cell. - 2008 - V. 14 - P. 183-192.

5. Hyun, Y. Generating and maintaining jasmonic acid in Arabidopsis / Y. Hyun, I. Lee // Plant Signal. Behav. - 2008 -V. 3 - P. 798-800.

6. Keramat, B. Effects of methyl jasmonate in regulating cadmium induced oxidative stress in soybean plant (Glycine max L.) / B. Keramat, K.M. Kalantari, M.J. Arvin // Afr. J. Microbiol. Res. - 2009 - V. 3, № 5 - P.240-244. 
7. Agrawal, G.K. Rice octadecanoid pathway / G.K. Agrawal [et al.] // Biochem. and Biophys. Res.Commun. - 2004. - V. 317, № 1. - P. 1-15.

8. Creelman, R. Biosynthesis and action of jasmonates in plants. / R. Creelman, J.E.Mullet // Annu. ReV. Plant Physiol. Plant Mol. Biol. - 1997. - V. 48. - P. 355-381.

9. Kolupaev Yu.E., Karpec Yu.V. Zhasmonovaya kislota u rastenij: sintez, signaling i fiziologicheskie effekty pri stressah // Vestnik Har'kovskogo nacional'nogo agrarnogo universiteta seriya biologiya. 2010. Vyp. 1 (19). S. 21-23.

10. Liechti, R. The jasmonate pathway. / R. Liechti, E.E. Farmer // Science. - 2002. V. 296. - R.1649-1650.

11. Kazan, K. Jasmonate signaling: toward an integrated view / K. Kazan, J.M. Manners // Plant Physiol. - 2008. - V. 146. - P. 1459-1468.

12. Anderson, J.M. Jasmonic acid-dependent increases in the level of specific polypep-tides in soybean suspension culture seedlings / Journal of Plant Growth Regulation. 2005. - V. 7. - R. $203-211$.

13. Ali, B.M. Methyl jasmonate and salicylic acid elicitation induces ginsenosides accumulation, enzymatic and nonenzymatic antioxidant in suspension culture Panax ginseng roots in bioreactors / B.M. Ali [et all] // Plant Cell Rep. - 2006. - V. 25, № 6. - P. 613-620.

14. Gao, X.P. Jasmonic acid is involved in the water-stress-induced betaine accumulation in pear leaves / X.P. Gao [et al.] // Plant Cell Environ. - 2004. - V. 27, №4. P. 497-507.

15. Hristova, V.A. Possible role of methyl jasmonate in protection to paraquat-induced oxidative stress in barley plants / V.A. Hristova, L.P. Popova // Dokl. B"lg. AN. - 2002. V. 55, № 8. - P. 99-104.

16. Farmer, E.E. Interplant communication: airborne methyl jasmonate induces synthesis of proteinase inhibitors in plant leaves. / E.E. Farmer, C.A. Ryan // Proc. Natl. Acad. Sci. U.S.A. - 1990. - V. 87. - R. 7713-7716.

17. https://studopedia.su/10_142881_lektsiya----sinteticheskie-regulyatori-rosta-irazvitiya-rasteniy.html

18. Gaspar, Th. Changing concepts in plant hormone action / Th. Gaspar [et al.] // In Vitro Cell Dev. Biol. Plant. - 2003. - V. 39, № 2. - P. 85-106.

19. Anderson, J.M. Jasmonic acid-dependent increase in vegetative storage protein in soybean tissue culture / J. Plant Growth Regul. - 1991- V. 10. - R. 5-10.

20. Neurasthenia, A. Inhibitory effects of methyl jasmonate on seed germination in maize (Zea Mays): effect on $\alpha$-amylase activity and ethylene production / A. Neurasthenia [et all] // Gen. Appl. Plant Physiology. - 2007. - V.33, (1-2). - P.13-23.

21.YaQian, L. Electrochemical behavior and the determination of methyl jasmonate / L. YaQian, W. Fang, C. Zilin // Chinese Science Bulletin. - 2010. - V. 55, (21). P. 2225-2230

22. Simultaneous determination of salicylic acid, jasmonic acid, methyl salicylate, and methyl jasmonate from ulmus pumila leaves by GC-MS / Zhi-hong Huang [et al.] // International Journal of Analytical Chemistry.- 2015.- Article ID 210503 